\title{
Impact of climate change on Hungarian Water Management Strategy
}

\author{
László Balatonyi ${ }^{1}$ \\ ${ }^{1}$ General Directorate of Water Management of Hungary, Márvány str. 1/D, Budapest, H-1012, Hungary
}

\begin{abstract}
One of the pillars of the Hungarian Water Strategy is preparing for the expected effects of climate change. Changes in the spatial and temporal distribution of water is the major challenge for Hungarian Water Management Service. Hungary is threatened by the phenomenon of water surplus and water scarcity at the same time, and making efforts to overcome all these is not only engineering task. As the impacts of climate change are getting more powerful the situation gets more complicated. The three biggest floods on the Danube happened in the last two decades, whereas on the Tisza four record breaking flood occurred within 36 month around the millennium. The floods of the past 20 years made it clear that extreme floods have to be reckoned with in Hungary. The extremities affecting the economy made the Hungarian water management reforms necessary. The periods of water surplus have resulted in extreme floods in streams over the past 20 years. The increasing flash floods have multiplied local water damages, and the frequency of urban floods has reached unprecedented levels.
\end{abstract}

\section{Introduction}

"Water is life's one essential resource and without quality and quantity safety measures the accepted UN Sustainable Development Goals (SDGs) of 2015 cannot be sustained by the year 2030."

Climate change has increased the pressure on Hungary's fresh water sources and in many regions the demand and availability are not in balance. Extreme weather conditions, as consequences of climate change, have a negative effect on water resources, environmental safety and the long term social compatibility of Hungary. Higher demand and increased challenge of various economic sectors for ever decreasing water resources can be predicted. Climate change demands more attention and sustainable water usage needs to be a priority.

National and social benefits can only be sustained in case water resources are managed by strict economic and engineering standards and watershed wide planning in Hungary. Water resources can never be managed only by accepting engineering capacities. Officials need to manage complete watersheds by carefully balancing different economic sectors' financial and social demands.

Future climate predictions have to be taken into account in any scientific research, program or strategy and the completed documents will need to be double checked by dedicated professionals.

\section{Climate change}

Nowadays is no question about the change of the climate, it's happening right now and we all feel it on our skin. Almost all of the countries lack the capacity to cope with extreme weather phenomenon, such as floods, flash floods, water scarcity, droughts and ice events. In Europe, more frequent and heavier droughts, rainfalls and heatwaves are forecasted or already observable as clear indications of climate change (IPCC, 2014) and pushing actions based on different levels, such as well as governance territorial (Macro-regional, Europe, countries, city) as watershed based (Danube basin).

\subsection{Macro-regional Strategies}

A 'Macro-regional strategy' is an integrated framework endorsed by the European Council to address common challenges faced by a defined geographical area relating to EU Member States and third countries located in the same geographical area which thereby benefit from strengthened cooperation contributing to achievement of economic, social and territorial cohesion.

Four EU macro-regional strategies, covering several policies, have been already adopted:

- EU Strategy for the Baltic Sea Region (2009)

- EU Strategy for the Danube Region (2010) 
- EU Strategy for the Adriatic and Ionian Region (2014)

- EU Strategy for the Alpine Region (2015)

In order to increase growth and strengthen cooperation at a macro-regional level the European Union adopted the EU Strategy for the Danube Region (EUSDR) in 2011 with eleven priority areas to harmonise development policies connecting fourteen countries on the Danube basin.

Hungary, together with Slovakia has been assigned to coordinate the Water Quality Priority Area (PA4) and to ensure integrated water management towards reaching the good quality of waters in the Danube River Basin. EUSDR PA4 aiming at to maintain and restore the quality of waters, to 'safeguard Europe's water resources', furthermore, to assist in the implementation of the EU Water Framework Directive and the Urban Waste Water Treatment Directive. EUSDR PA4 gives a hand, e.g. in the promotion of measures addressing wastewater treatment measures in non-EU countries, the facilitation of sub-basin activities or the improvement of fish migration.

The coordination of the Environmental Risks Priority Area (PA5) is managed by Hungary and Romania. The main focus of the work is to address the challenges of water scarcity and droughts in line with the Danube River Basin Management Plan, the report on the impacts of droughts in the Danube Basin in 2015 (due in 2016) and the ongoing work in the field of climate adaptation. Therefore, in the past few years EUSDR PA5 contributed to the elaboration of the ICPDR Climate Change Adaptation Strategy Update 2018, supported project elaboration and implementation in the field of drought management and climate change related spatial planning, disseminate scientific results to anticipate regional and local impacts of climate change through research. Flood risk management is also a significant target of the priority area. In order to achieve reduction of flood risk events EUSDR PA5 provides and enhance continuous support to the implementation of the Danube Flood Risk Management Plan. In case that these prevention measures are not effective enough, than disasters occur, therefore EUSDR PA5 supporting the assessment of disaster risks in the Danube Region, encouraging actions to promote disaster resilience, preparedness and response activities. In 2019. there was established the Disaster Management Working group for the coordination the relevant activities among 14 Danube countries.

\subsection{Climate change in the Danube basin}

An intensification of extreme events, such as floods and droughts, leads to high impacts for agriculture, forestry and industry, as well as built-up areas and infrastructure. As a consequence of decreasing water availability, a shortage in water supply is expected in some areas. There will not be enough water to meet the requirements for irrigation in agriculture and the vegetation period will shorten in large areas in the south of the Danube River basin (hereafter: DRB). In contrast, in the northern parts there will be enough water for productive farming. A shift in species distribution and an increasing risk of invasive species is expected due to changing climatic conditions.

An increase in air and water temperature, combined with changes in precipitation, water availability, water quality and increasing extreme events, such as floods, low flows and droughts, may lead to changes in ecosystems, life cycles, and biodiversity in the DRB in the long-term. This is frequently mentioned to be one of the most relevant climate change impacts (ICPDR, 2018)

\subsection{About Hungary}

Hungary is a flatland in the Carpathian Basin surrounded by the Alps, the Carpathians and the Dinaric Mountains. The huge volume of water flowing down from the mountains slows down on the plains, gets barred, ponded and drifts through the country causing extreme floods. The record floods of the last two decades had the Hungarian experts reconsider their view on flood control. The analyses have proved that the old methods of protection are not adequate anymore. The dykes getting ever higher represent an increasing risk on the population. The constant heightening of the $4.425 \mathrm{~km}$ long dyke system would put an enormous economic burden on the country.

At the same time the expectations of the population have significantly changed as well. While in the 19th century flood control, the protection of arable land, and to have as much farmland as possible was demanded, nowadays the protection of natural values, the improvement of ecological services, recreation and nature conscious solutions came into the foreground.

Accordingly flood control often had to fulfil opposing conditions. The citizens expect the government to provide them the European standard, the protection against floods occurring once in a century. However there is an excessive need to create wetland areas, rehabilitate oxbows, establish recreational opportunities, protect flood plain forests, protect and increase biodiversity. The rising popularity of water sports and hiking requires the creation of natural riverbed sections, the demolition of water control facilities and the focus on natural hydromorphological processes. On the other hand, every activity or development that puts newer and newer obstacles in the way of the flood degrades flood safety.

As the impacts of climate change are getting more powerful the situation gets more complicated. The three biggest floods on the Danube happened in the last two decades, whereas on the Tisza four record breaking flood occurred within 36 month around the millennium.

The floods of the past 20 years made it clear that extreme floods have to be reckoned with in Hungary. In Hungary there were measured extreme flood in 2002 ( 848 $\mathrm{cm}$ ), 2006 (860) and the biggest 2013 (891), however during that period was also recorded the lowest level (33 $\mathrm{cm}$ ) in 2018 (1. Figure). The water level is slowly decreasing $\left(y=-0,0076 x+554,89 R^{2}=0,031\right)$. 


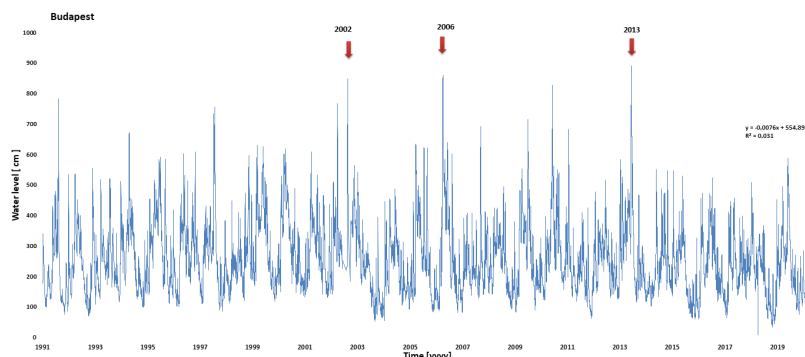

1. Figure Water levels in the Budapest section of the Danube River

During six days of constant precipitation (30.05.03.06.2013) along the Northern Alps form Bavaria to the Czech Republic a substantial flood event occurred. In total more than $400 \mathrm{~mm}$ of precipitation had been measured which is about the half-year sum, whereas these sums met mainly moist to saturated conditions due to intense rainfalls prior to the event. The individual daily precipitation sums were not exceptionally high (ICPDR 201. It was the accumulation over the four days from the $31^{\text {th }}$ of May to the $3^{\text {nd }}$ of June that ultimately resulted in extreme flooding (2. Figure).

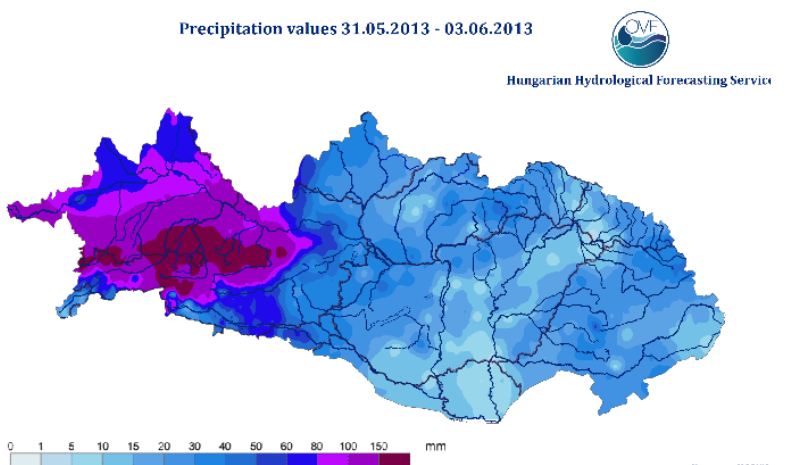

2. Figure The precipitation during 31.05.2013 - 03.06.2013

The extremities affecting the economy made the Hungarian water management reforms necessary. It is to ensure the availability of water, water services (drinking water, irrigation, other water withdrawals), and water damage prevention with measures that are standardized on a river basin level. Within the framework of water damage prevention it is to handle - with an integrated organization:

- excess water and drought protection, with the establishment of dual-operation, water supplementary and drainage system

- flood control against design flood levels with the improvement of the flood plains and the flood protection lines

- extreme water balance situation caused by climate change with the establishment of water reservoir systems.

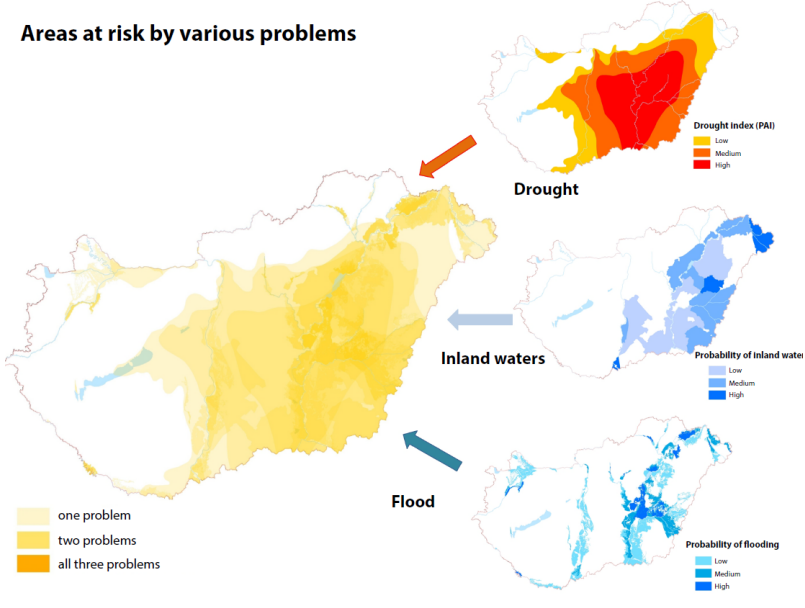

3. Figure Water related risks in Hungary

The impacts of climate change are getting more powerful the situation gets more complicated. The three biggest floods on the Danube happened in the last 10 (15) years, whereas on the Tisza four record breaking flood occurred within 36 month around the millennium!

But if we talk about the damages of the surplus of water, we have to say a few words about the problems caused by the lack of water. 2002, 2003, 2012 were extremely dry years. Although droughts did not cause severe problems in Hungary as in other parts of the world, but it is becoming a factor that has to be calculated with. The floods of the past 20 years made it clear that extreme floods have to be reckoned with in Hungary.

\section{Climate adaptation}

Extreme conditions and intense weather events (droughts and floods) test the capacities of the involved institutions (catastrophe protection agencies, local governmental offices and the water sector) and their economies. There is an increasing trend in the formation of local (point source like) extreme storms and precipitation, which demand quick and effective responses. Most likely these situations will force investment in damage prevention measures, but in any case, flash floods (floods within 6 hours) will happen more often in mountainous areas, where people will have to accept much higher risks (Pirkhoffer et al. 2009a, 2009b, Czigány et al. 2010). In the last 10 years, or last 6 years to be more precise, these extreme rainy days have become more numerous and their damage more serious (2. graph). Infrastructural and other measures will have to be improved to decrease the risks.

Hungary's water management has one primary goal, to retain water in the area, but precipitation is not generally well-managed in our country. Good practices of precipitation as a resource are not well known or accepted. Our towns and cities, the centres of population, infrastructure and industry, are the most vulnerable to climate change and the consequences of extreme weather events, since most of our towns are located directly in the most sensitive geographical areas. Cities' water management systems (safe drinking water, precipitation 
and sewage management infrastructure) will have to endure the changes of the water cycle (Buzás 2015).

\subsection{Hungarian Water Management Strategy}

Hungary's National Water Management Strategy (the 'Kvassay Jenö Plan', hereafter: KJT) emphasizes the importance of precipitation management, the prevention of contamination and uncontrolled flow of precipitation, to safely maintain surface and ground water resources and to decrease pressure on our infrastructure, while trying to keep most of this unused water resource in place.

The subject of the KJT is water, but not only. That environmental component to which every member of the society relates somehow (starting from the individual through the economic sphere to the state), either as enjoying the benefits or suffering from the damages caused by water. The scope extends to the whole territory of the country:

- surface and subsurface waters, their beds, banks and water storing formations;

- all establishments and activities that influence or change the runoff and streaming conditions, quantity, quality, including public water supply and wastewater systems;

- management of water resources, exploration of water use possibilities including conservation and improvement of the role of the water in nature;

- prevention and protection from the damages of water;

- survey and exploration of the state of waters, their assessment, research, observation, data collection, processing, dissemination and use;

- the state of the water as habitat and activities influencing it as a landscape forming factor

The KJT is the strategy of the Hungarian water management extending to 2030 and the middle term action plan until 2020. It drafts the activities to do on the basis of the exploration of the relation between water and society in order to

- enable our country to avoid the water crisis threatening the world, to take necessary measures in time against its already observable signs,

- preserve the water for the next generation, because it is the condition of life, the prime mover of the economy that cannot be substituted by anything else,

- use its benefits efficiently,

- enough security against its threatening damages.

The character of the task required the harmonisation of the ecological, technical, social and economic aspects. Methodological assistance was given to this by the DPSIR frame model (driving forces - loads - states - impacts responses). Most of the measures needed for the execution of the strategy can and should be effectuated in the 20142020 programming period. They fit into the EU2020 strategy and the EU cohesion and structural political conception for the period 2014-2020. The strategy has four main elements (4. $\quad$ Figure

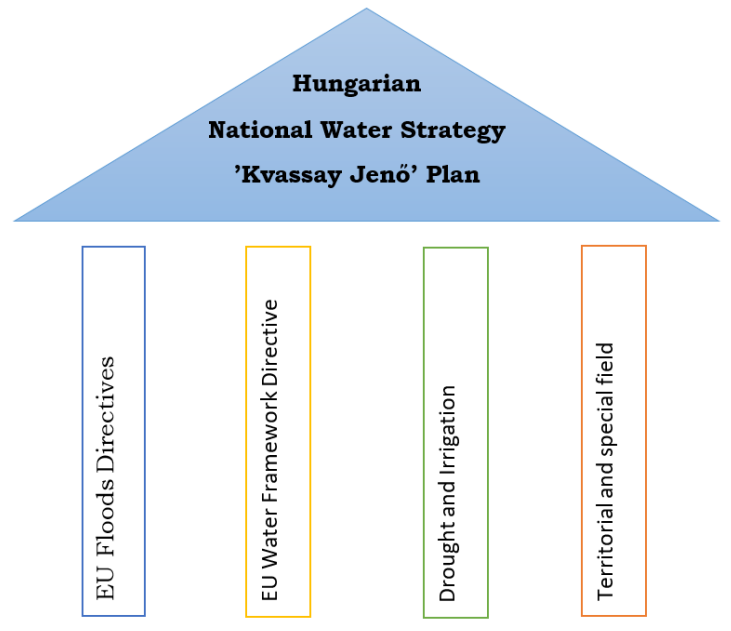

4. Figure Pillars of the Water Strategy (Source: Author's illustration).

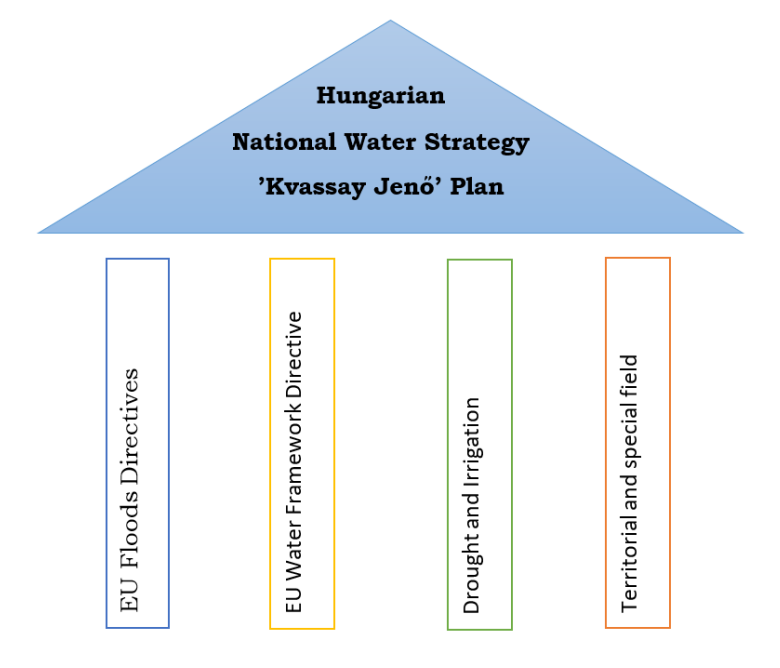

4. Figure Pillars of the Water Strategy (Source: Author's illustration)

\subsection{Flood Risk Management in the Daube basin}

Directive 2007/60/EC on the assessment and management of flood risks (Floods Directive, FD) requires the EU Member States to assess if all water courses and coast lines are at risk from flooding, to map the flood extent and assets and humans at risk in these areas and to take adequate and coordinated measures to reduce this flood risk. This Directive also reinforces the rights of the public to access the information on flood risks and on related measures and to influence the planning process. On the Danube basin the

International Commission for the Protection of the Danube River (hereafter: ICPDR) is the coordinating body among the countries (especially the Flood Protection Expert group). The EU Member States shall coordinate their own flood risk management practices with all countries sharing an international river basin, including non-Member States, 
and shall in solidarity not undertake measures that would increase the flood risk in neighbouring countries. In addressing the Directive 2007/60/EC the Member States shall take into consideration long term developments, including climate change and sustainable land use practices.

According to FD the Member States shall, at the level of the river basin district, or unit of management, prepare flood hazard maps and flood risk maps, at the most appropriate scale for the areas identified under Article 5(1). The preparation of flood hazard maps and flood risk maps for areas identified under Article 5 which are shared with other Member States shall be subject to prior exchange of information between the Member States concerned.

Flood hazard maps shall cover the geographical areas which could be flooded according to the following scenarios:

- floods with a low probability, or extreme event scenarios;

- floods with a medium probability (likely return period $\geq 100$ years);

- floods with a high probability, where appropriate.

- each scenario the following elements shall be shown:

- the flood extent;

- water depths or water level, as appropriate;

- where appropriate, the flow velocity or the relevant water flow

Flood risk maps shall show the potential adverse consequences associated with flood scenarios referred to above and expressed in terms of the following:

- the indicative number of inhabitants potentially affected;

- type of economic activity of the area potentially affected;

- installations as referred to in Annex I to Council Directive 96/61/EC of 24 September 1996 concerning integrated pollution prevention and control which might cause accidental pollution in case of flooding and potentially affected protected areas identified

- other information which the Member State considers useful such as the indication of areas where floods with a high content of transported sediments and debris floods can occur and information on other significant sources of pollution

For coastal flooding where there is an adequate level of protection in place, and for groundwater flooding, Member States can decide to limit the preparation of flood hazard maps to low probability or extreme events (art 6.6 and 6.7).

\subsection{Flood risk management in Hungary}

Based on the different scenarios' extents the necessary risk evaluation was carried out in separate maps (5. Figure) for proper visualization.

- Population affected: estimated number of inhabitants who live in settlements that are spatially overlapping with the inundation (2001 data). The indication of the value is the size of the dot mark.

- Economic activity: the classification is based on the CORINE land cover data set. The important roads and railways, SEVESO objects, power plants, sewage treatment plants, harbours, airports and other industrial facilities were added from the river basin management plans.

- IED installations: the E-PRTR facilities were taken in account on the maps with harmonized classification.

- WFD protected areas: updated data from the river basin management plans were used, such as freshwater sources, recreational areas and protected landscapes. The surface water affected groundwater is also presented.

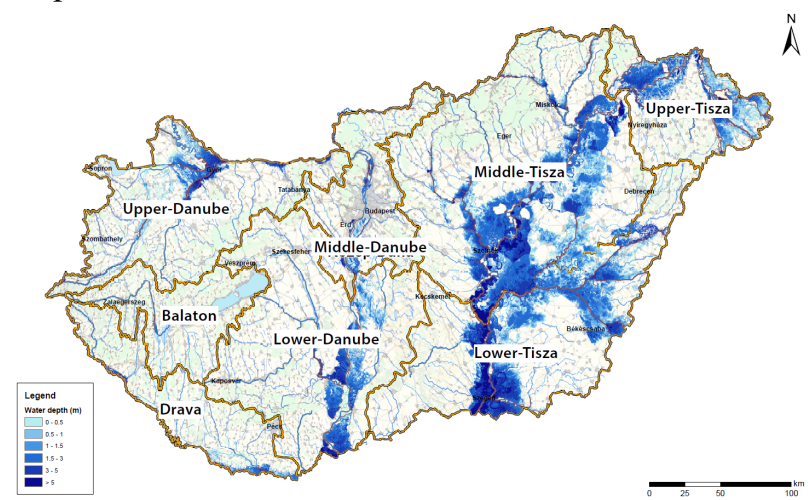

5. Figure 100 year return period floods affected areas in Hungary (Source: General Directorate of Water Management of Hungary)

\subsection{Flood Plain Management Plans}

Between the periods of 1998-2013 extreme floods beyond the previous water levels developed with unprecedented rapidity on the rivers of Hungary. While flood discharges are not increasing, water levels are intensely rising (e.g. water level of the river Danube at Budapest broke a record 3 times - 2002, 2006, 2013 - in 10 years), which primarily originates in the continuous reduction of the flood plain's water deliverer ability. That fact pointed out that edifices, feral agricultural territories, proliferation of the forests' underwood located in the flood plain, restrain the natural territory of the river and create a heavy runoff obstacle in case of floods. The negative procedure in the flood plain in addition to the rising of peak water levels, results in the persistent remission of the safety and thus the value of the flood protection objects/projects built from the budget. Thus the budget source covered by the tax-payer's money cannot reach its goal.

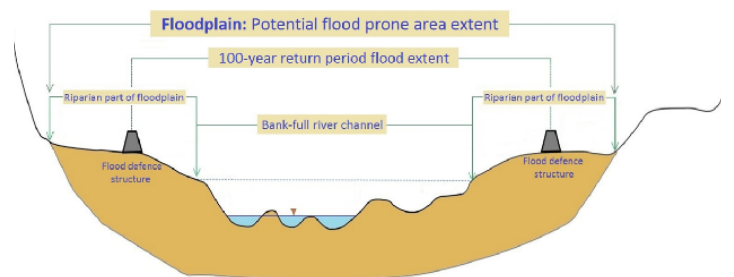

6. Figure Definition used to characterize the floodplain (Source: Author's illustration) 
Besides this, the expenses of the further boost of flood protection dykes are exponentially rising, not only because of the size of the dyke, but also because of the amount of salient waters arousing through growing water pressure. This requires the reforming of the water system of the protected areas too. That fact demanded necessity to stabilize the location of flood and the flood plain, and to avoid its further destruction.

For the safe drainage of floods, Hungary has developed a special hydrodinamycal modelling process, of which it can be optimized the flood drainage in the flood plain and the economic and public activity in the flood plain. The developed modelling process and the measures defined according to these ensure to stabilize the maintenance and drainage capacity of the flood plain, avoiding the further increase of peak water levels.

\subsection{The definition of new design flood levels}

The recent flood waves of the Danube - the biggest river of Europe - have recurrently broke the record flood levels of the past 100-150 years. The more frequently occurring flood peaks made it necessary for the water management to generally supervise the earlier defined Design Flood Levels (DFL), that are fundamental for the development and construction of the protection system.

The newly developed methodology is based on scientific grounds - besides the previous system based on water levels and water level statistics, it defines the DFL levels by the statistics of water flow. Furthermore with generating time series based on possibly available data it can widen the database of 50-100 years to several thousand. Thus with taking the water flow statistics into consideration and evaluation, taking the riverbed condition into calculation, the widened database made it possible to define a professionally sound design flood level for every river in Hungary.

\subsection{Differentiated flood control}

Based on the water management development strategy, a large number of embankments were built before 2000 to ensure safety. However the flood control experiences of the last 30 years in Hungary have proven that, besides developing dyke systems along the rivers and building them to the specified size, applying new methods and solutions is also needed, therefore, besides others, regional flood control systems have to be deployed.

After 2000 - to prevent the effects of climate change - the development of reservoirs became increasingly important. Due to the high flood levels in 2010s, flood bed management plans were completed in 2015 to preserve protection level.

It is foreseeable that reaching the necessary dyke elevations will not be possible in the next 30 years. This is the reason why the system of differentiated flood control, which is the only solution for the rational management of the ever-increasing floods due to climate change, needs to be introduced.
Differentiated flood protection has emerged as a national risk management variant during the preparation of the flood risk management plan.

The alternative, differentiated by basins, contains two significant differences from the current version:

- differentiate between design flood levels

- heights of dykes are only determined by technical considerations

To introduce differentiation, it is recommended to quantify the technical and economic aspects on the basis of which we can determine the levels of protection. This requires the following aspects:

- Protected or affected populations in basins

- Protected economic value or estimated flood damage in basins

- Ranking of affected populations and economic value

- Time advantage for each basins

- subsoil and cross section problems

- Distances between dykes

- Engineering safety flood level

- Results and impact of developments up to 2020

- Impact of river basin management plans

\section{Urban water management}

In the cities, precipitation management also has other important benefits for the people and the environment, for example microclimate control and higher biodiversity. Precipitation utilization (control, preservation and further usage) is undoubtable one of the main goals of the water management sector, but it is also perhaps the most challenging concept, since all input factors (precipitation intensity and potential maximum in given area and time) shift rapidly, hence the management infrastructure engineering has to cope with these new conditions.

\section{Prevention, Preparation and Recovery}

The Hungarian water sectors' approach toward damage response have been divided, according to the available time scale, to prevention, mitigation and damage repair action plans. Cost and benefit studies have concluded that prevention and mitigation is generally much cheaper than repair (Balatonyi et al 2018). This is true in general, but also on local scales, especially for municipal measures, both on a logistic scale and in an informal way as the background principle to influence local peoples' thinking of the problem (either as individuals, or as locals with selfgovernance, or as part of a larger, regional group).

Either way, the main goal is to prevent problems caused by the water and to save water quality. This excess water can be utilized as a resource:

- For irrigation,

- For personal household reuse,

- Just for temporary storage to prevent flood damage,

- For setting important examples in local communities (with sanctioning)

To successfully adapt to these new challenging conditions, we must approach these problems both from a 
qualitative (keeping the water flow in control) and a quantitative (water pollution prevention) perspective. Most of the mountainous areas in Hungary already have preventive systems in place, but these are mostly old and were not modelled to mitigate the risks of current and future events.

First, we will have to update our risk assessment, by carefully studying the previous 30 years' maximum precipitation records (Buzás, 2012). Until new models are generated with updated calculations, we can assume that our safety systems are outdated, and local floods will occur. Furthermore, without updated models, even our new preventive measures will be as outdated as the old ones.

Climate seems to change as fast as we reconstruct municipal water outlets, so it is possibly the only feasible economical option to focus on local water storage potentials (increasing storm water storage capacities and groundwater inflow).

\subsection{Options for Water Storage}

The most effective way to prevent flooding in low hill and mountainous areas is to provide storage options around the watershed perimeter, at the source and not where water accumulates. It is also true, that the best way is to start retaining water at individual owners' grounds, and only step up as reassurance on the local and national level.

Precipitation events can be categorized by their intensity as follows:

Approximately, below $20 \mathrm{~mm} \mathrm{hr}^{-1}$ the best option is to use "green tech" to increase ground water recharge at the local grounds. Above this intensity, local governmental infrastructural management is needed, with some designated areas that can be temporarily flooded. The most extreme events might demand regional infrastructure investments.

\section{Engineering Tasks for Future Municipal Storm water Management}

Extreme weather conditions can lead to disagreement and conflict between various dependent groups. People are getting used to constant, reliable improvement of their lives, and they also want the government to provide complete safety about the ever increasingly unpredictable weather. This should not be accepted by the central governance. People will have to realize their own responsibility. We might accept and try to control the discourse about the water level control of lake Balaton (is a freshwater lake in the Transdanubian region of Hungary. It is the largest lake in Central Europe), but local problems will have to be solved in situ. Even so, it is inevitable that we will have to construct strict laws for the reginal and central governance.

Economics, engineering concepts and laws will all have to be taken into account to create a reliable and somewhat flexible but complete strategy for the future. Local resources, the capacities of towns and their people will be the main controlling factors of course, but the concepts should be clear, and these all depend on new, updated calculations and models:

- Average precipitation and overflow calculations, based on a reliable, up-to-date data collection system,

- New models, pilot projects and predictions as basic info's for everyday practices,

- Informing the general public about the challenges and their responsibilities as responsible citizens,

- Previous events' scientific studies and their results evaluations.

We will need to translate and incorporate international standards and good practices' guidelines into our national approach to be up to these new challenges. We will also have to categorize each town and city by their geographic vulnerability into groups and to help the local governance to update their strategic plans by educating them about the new potential risks.

Precipitation can be utilized by individuals as safety water for gardening during drought, or even for household usage. These methods' costs and benefits are not well known by people, so they tend to ignore the question. We will have to research the most economical ways that we can promote on a national scale.

\section{Laws and Coordination}

It must have been identify the most relevant national laws and rules for each specific situation to be able to decide who is responsible, the individual, or the local or central governance.

Generally speaking, each individual with a property has a direct effect on how precipitation will flow. (Green gardens and concrete grounds have obviously totally different absorption capacities.) Public service providers cannot be "punished" to deal with the entire overflow from gardens, when their contracts don't even include rainwater management. Although this should be included in their contracts as basic public utility service (Buzás 2015.) it would be unfair to generally ask for a fixed extra price from every citizen. Instead people's payments should be based on the size and condition of their properties.

\section{Economics background of Municipal Precipitation Management}

As mentioned, people shouldn't rely on the central governance for fixing their own problems and local governance will have to be responsible to study and evaluate their environmental and economic situation, since they are mostly dependent on long term local stability. EU sources can be part of larger investment projects' financial support and the central governance can also help, but local people have to realize it is mainly their responsibility.

\section{Where Do We Stand Now}

Most people have already realized that climate change is not just a concept and extreme weathers are real risks. Local actors try to do what they can with limited resources, mainly to keep existing infrastructure functioning. The 
central governance's public works program (temporary jobs for unemployed people) helps in the maintenance of old infrastructure, but for new largescale engineering projects, EU sources are also needed.

We, water professionals try our best to update our formulas and models and to educate people about their possibilities, since most local town governance offices do not have a dedicated referee to these tasks.

\section{References}

1. Balatonyi, Makay and Tóth (2019): A közelmúlt globális klímaváltozásai, helyi vízkáreseményei és költségvetési következményei a dél- dunántúli kis vízfolyásokon

2. Buzás (2015) A városi vízrendszerek megújítása, a klímaváltozáshoz való alkalmazkodás növelése

3. Buzás, K. (2012): Települési csapadékvíz gazdálkodás, Monográfia, Terc kiadó, 2012. 148 old.

4. Czigány, S, Pirkhoffer, E, Balassa, B, Bugya, T, Bötkös, T, Gyenizse, P, Nagyváradi, L, Lóczy, D and Geresdi, I. (2010): Villámárvíz, mint természeti veszélyforrás a Dél-Dunántúlon Földrajzi Közlemények 134(3): 281-298.

5. International Commission for the Protection of the Danube River (2018): Climate Change adaptation strategy, https://www.icpdr.org/flowpaper/app/services/view.p hp?doc=icpdr climatechangeadaptationstrategy 2.pd f\&format $=$ pdf\&page $=\{$ page $\} \&$ subfolder $=$ default $/$ file s/nodes/documents/

6. International Commission for the Protection of the Danube River (2015):1st DRB Flood Risk Management Plan, https://www.icpdr.org/flowpaper/app/\#page=2

7. International Commission for the Protection of the Danube River (2013): Floods in June 2013 in the Danube River Basin https://www.icpdr.org/main/sites/default/files/nodes/ documents/icpdr_floods-report-web_0.pdf

8. Intergovernmental Panel on Climate Change (2014): Summary for Policymakers. In: Climate Change 2014: Impacts, Adaptation, and Vulnerability. Part A: Global and Sectoral Aspects. Contribution of Working Group II to the Fifth Assessment Report of the Intergovernmental Panel on Climate Change [Field, C.B., V.R. Barros, D.J. Dokken, K.J. Mach, M.D. Mastrandrea, T.E. Bilir, M. Chatterjee, K.L. Ebi, Y.O. Estrada, R.C. Genova, B. Girma, E.S. Kissel, A.N. Levy, S. MacCracken, P.R. Mastrandrea, and L.L. White (eds.)]. Cambridge University Press, Cambridge, United Kingdom and New York, NY, USA, pp. 1-32.

9. Pirkhoffer, E., Czigány, S. and Geresdi, I. (2009a): Modeling of flash flood events in a small lowmountain watershed in SW Hungary

10. Pirkhoffer, E., Czigány S. and Geresdi, I. (2009b): Occurrence of rainfall pattern on the occurrence of flash floods in Hungary Zeitschrift für Geomorphologie 